RAINBOW Vol. 8(2)(2019)
UNNES Journal of Literature, Linguistics and Cultural Studies
$\underline{\text { http://iournal.unnes.ac.id/sju/index.php/rainbow }}$

\title{
Ethical Dilemmas as Seen Through the Major Characters Reflected in The Danish Girl Movie Screenplay Written by Lucinda Coxon
}

\author{
Kemala Putri Anggraeni ${ }^{\bowtie}$, Maria Johana Ari Widayanti \\ English Department, Faculty of Languages and Arts, Universitas Negeri Semarang
}

\begin{abstract}
Article Info
Article History:

Received 15 October

2019

Approved 29 November

2019

Published 30 November 2019

Keywords: Characters, Ethical Dilemma, Movie Screenplay,

Psychoanalytic Theory, The Danish Girl,

Abstract

An ethical dilemma is an interesting topic to discuss since it always occurs to us in our daily lives whether we realise it or not. The study is aimed to explain the ethical dilemmas of the major characters in The Danish Girl movie screenplay by Lucinda Coxon. This study used psychoanalytic theory of the tripartite model theory by Sigmund Freud and employed qualitative method. The result was the ethical dilemmas of the major characters occurred before they made a decision in their actions. This study revealed that the ethical dilemma happened to them because they needed to think about the impact of their actions on other people or themselves. It could prevent them from doing or saying inappropriate things which could hurt someone's feelings or harm themselves. Another result in this study was that the ethical dilemmas that happened to the major characters mostly represent ego more than the other two parts of psyche. They could control what they wanted to say or do since they thought about the possible things that could happen to each choice before they made the decision.
\end{abstract}




\section{INTRODUCTION}

Every human being in everyday life is faced with choices that require them to choose one of the choices. The need to choose one of the choices often leaves them in a dilemma situation. A dilemma can occur anywhere and anytime, both in business and personal terms. This can happen because humans want to choose the best from the choices. But the problem is that every human being must have different the best criteria. According to Figar \& Đorđević (2017), basically, every dilemma contains an ethical dilemma (ED), i.e. whether the decision is good/bad, fair/unfair, moral/immoral. Every human being has to think of other things before making a decision, such as whether the decision chosen is good, fair and appropriate for themselves and others. This is done to avoid making wrong decisions which can be detrimental to themselves and others.

According to White (1998), ethics is the branch of philosophy that explores the nature of moral virtue and evaluates human actions. Generally speaking, there are two traditions in modern philosophical ethics regarding how to determine the ethical character of actions. One argues that actions have no intrinsic ethical character but acquire their moral status from the consequences that flow from them. The other tradition claims that actions are inherently right or wrong, e.g, lying, cheating, and stealing. The former is called a teleological approach to ethics, the latter.

Figar \& Đorđević (2017) said an ethical dilemma is a situation of making a choice between two or more alternatives. An agent is in unpleasant and difficult situation because he/she often needs to make a choice between ethical and unethical alternatives, and when it comes to the ethical alternatives, he/she should choose the best one. The selection reflects to a large number of principals, so this situation causes conflicts between different levels of ethical dilemmas, but also the conflicts within the same level. These conflicts can be solved by applying the hierarchy and priority rules which are incorporated in the procedure and, in particular, in the strategy for solving the ethical dilemmas.

According to Laine (2000), an ethical dilemma may be described as a problem for which no course of action seems satisfactory; it exists because there are 'good' but contradictory ethical reasons to take conflicting and incompatible courses of action. Ethical decision making includes being consciously aware of one's values, principles and allegiance to ethical codes, intuition and feelings, within a context that is characterized by professional and power relationships. It means that ethical dilemmas are situations in which there is no 'right' decision, 'only a decision that is thoughtfully made and perhaps "more right" than the alternatives'.

An ethical dilemma refers to a situation that often involves complex and conflicting principles of ethical behaviour because no clear guideline is available on how to act and respond to a specific problem (Kitchener, 1984). In addition, it is important for an individual to recognize the presence of an ethical dilemma since ethical dilemma acts as a catalyst for the entire decision-making process (Hunt \& VasquezParraga, 1993). It occurs because ethical decisionmaking criteria will not be employed if the existence of an ethical dilemma is unrecognized (Jones, 1991). That makes ethical dilemma vital to study since it will consequently lead to ethical actions.

The movie screenplay, itself, has an interesting plot since it is based on a true story. According to IMDb (2015), The Danish Girl tells real-life renowned painter artist Einar Wegener shares a strongly-bonded and filled with love marriage with his less recognised portraitist wife, Gerda. Although they are different, the very foundation of their relationship is about to be compromised, when one day, Gerda will playfully ask of Einar to fill in for one of her female models and pose for her painting dressed in a marvellous dress. Unobtrusively, this life- 
changing experience will trigger a subtle transformation inside Einar, who will begin to realise that, in reality, he is Lili, a woman trapped in a man's body, and that his real, true self should start living as a proper woman. As more and more it will become evident that this is not an ephemeral caprice, Einar determined to live his new life to the full, will boldly attempt amidst prejudice, discrimination, social dictations, and of course, public outcry, to fight for the right to be different and undergo a highly experimental sex reassignment surgery that would eventually make Lili a notable transgender pioneer.

Thus, based on the explanations above, the studyer will explain how such ethical dilemma of the major characters are explained in The Danish Girl by using quotations of the movie screenplay. The studyer will explain it using the tripartite model theory by Sigmund Freud.

\section{METHODS}

This study is a descriptive qualitative study since it explained about the ethical dilemmas of the major characters in form of words, clauses, sentences, and dialogues. Burns and Grove (2003:19) describe a qualitative approach as "a systematic subjective approach used to describe life experiences and situations to give them meaning". Studyers used the qualitative approach to explore the behaviour, perspectives, experiences and feelings of people and emphasize the understanding of these elements. The studyer focused on the experiences from the participants' perspective. In order to achieve the emic perspective, the studyer became involved and immersed in the study.

This study applied the tripartite model of psyche of Sigmund Freud. The theories and practice of Sigmund Freud provide the foundation for psychoanalytic criticism (Bressler, 1999:149). This approach attempts to explain the hows and whys of human actions without developing an aesthetic theory - a systematic, philosophical body of beliefs concerning how meaning occurs in literature (Bressler, 1999:148). According to Bressler (1999:150), Freud separated the human psyche into three parts which called the tripartite model. This model consists of three parts: the id, the ego, and the superego.

The first object of this study was the material object that was a movie screenplay written by Lucinda Coxon entitled The Danish Girl hosted by Focus Features which contained 90 pages. It was an adaption from the novel with the same title by David Ebershoff. The second object was the formal object that was the study of the screenplay seen from the study question which was the major characters of the screenplay those were Einar Wegener and Gerda Wegener. It would limit the study so the study would not come out of the topic.

The data were collected by reading, identifying, classifying, and inventorying. The collected data were analysed by explaining the ethical dilemmas of the major characters of Lucinda Coxon's The Danish Girl movie screenplay. The data were also analysed by explaining the ethical dilemmas based on Freud's tripartite model theory of psyche (id, ego, and superego).

\section{RESULTS AND DISCUSSIONS}

\section{Ethical Dilemmas of The Major Characters In The Danish Girl Movie Screenplay}

Figar \& Đorđević (2017) explained that when someone is in a situation where he/she has to make a choice between two or more alternatives, it means he/she is experiencing an ethical dilemma. Experiencing ethical dilemmas often leaves a person in an uncomfortable and difficult situation because he/she needs to make a choice between ethical and unethical alternatives. When it comes to ethical alternatives, he/she must choose the best one. Since the choice reflects a large number of principals, this situation causes conflicts between 
different levels of ethical dilemmas, but also the conflicts within the same level.

The analysis of the ethical dilemmas based on the tripartite model theory of Sigmund Freud can be seen below:

\section{The ethical dilemmas of Einar Wegener/Lili Elbe}

Einar Wegener was a shy and an introvert man. He did not like parties since he did not like to talk to people. Talking with others made him uncomfortable. He worked as a landscape painter and lived in Copenhagen with his wife, Gerda Wegener, who was also a painter. One day, Einar felt something in his body after posing as a woman for Gerda's portrait. He discovered his true self that was being a woman or Lili Elbe and determined to live his life as Lili and leave Einar behind. Lili was flirtatious, playful, and seductive. She is freer than the conflicted Einar. In this study, Einar Wegener/Lili Elbe's ethical dilemmas are portrayed in certain dialogues below, and analyzed by the Sigmund Freud's tripartite model of psyche.

GERDA (cont'd): No. I need the dress.

They both look over to where Ulla's dress hangs. It is white, weighted with beads at the hem and cuff. Beautiful.

EINAR: Gerda, I'm not putting on.

GERDA: I haven't asked you to.

She get sit... lays it across him.

(Coxon, 2015:11)

The first ethical dilemma on Einar occurred when Gerda asked Ulla, who was her best friend, to be the model of her painting. On the appointed day, Ulla told Gerda that she could not come because she had a rehearsal to do. Since Ulla cancelled the appointment, Gerda decided to ask her husband to become the model. She asked her husband to wear a dress that had been prepared. The ethical dilemma that happened to Einar here was when Gerda asked him to wear the dress. Einar did not know whether he had to grant his wife's request or refuse it. He felt bad if he refused to do what his wife alleged because he had promised to help his wife, which indicated his superego. However, Einar did not want to wear the dress since he thought a dress was not clothing worn by men. In the end, he decided to wear the dress. Here, Einar's desire that he did not want to wear the dress was his id. In other words, his id drove him to do or follow his will. Yet, his id and superego successfully were suppressed by his ego that was wearing the dress intending to make his wife happy.

GERDA: What is it...?

Einar's eyes shine animated. He cuts an ungainly figure, but the impression is more confusing than jarring.

EINAR: Am I pretty enough?

Gerda's surprised by the sincerity of the question.

GERDA: Of course you are...

(Coxon, 2015:22)

The second ethical dilemma on Einar occurred when Gerda and Einar were playing Gerda's game where Einar had to come to a party with her as Lili. He wore the dress that Gerda chose, and she also put makeup on Einar. His ethical dilemma appeared when he arrived at the party. Einar felt unsure about his appearance as a woman. He was afraid that people at the party would realize that Lili was Einar. He even asked Gerda about his appearance to make sure that he looked like a woman. It made Einar not sure to enter the ballroom, even though he was already there. His superego arose when he was afraid that people at the party would notice that he was dressing up as a woman and start judging him. Since he was a well-known portrait painter, he didn't want to ruin his career just because of Gerda's game. In the end, he decided to enter the ballroom. In this case, his desire to leave the party indicated his id. In other words, his id drove him to follow his desire. However, his id and superego were successfully suppressed by his ego, which made him go to the party in order to make his happy.

HENRIK: No, it's more than that. I feel I'd need to ask permission before I kissed you.

A bolt of something goes through Lili. Her eyes sink, drawn and repulsed, to Henrik's lips. She can hardly breathe...

EINAR/LILI: I probably ought to find Gerda. 
She heads back toward the corridor... Henrik grabs her hand.

(Coxon, 2015:27)

Next, Einar's ethical dilemma emerged when Einar/Lili and Gerda attended a party. There was a man who was attracted to her. That man was Henrik. He approached Lili, flirted with her, and tried to kiss her. When Henrik asked Lili for permission to kiss her, she did not know what to do or say to him. As we can see from the quotation above, instead of responding to what Henrik said, Lili turned the conversation around by saying that she should look for Gerda. It showed her ethical dilemma. She was afraid she would hurt Gerda if she kissed Henrik and was also afraid that Henrik would find out that she was Einar. However, she was flattered and happy when there was a man who liked her and wanted to kiss her. It made her feel like she was a completely natural woman. This also made her realize that she was a married man, and what she did was wrong, which indicated her superego. In the end, Lili tried to go back to the corridor and left Henrik behind. Here, the desire to kiss Henrik was her id, but her id and superego were being suppressed by her ego by trying to leave the place in order to not to hurt Gerda.

GERDA: But Lili doesn't exist. We made her up.

EINAR: I know..

GERDA: We were playing a game!

EINAR: I know we were... but then it changed...

Gerda's mind reels, panic rises...

GERDA: This is absurd. We need to stop.

Make it stop Einar.

With genuine anxiety:

EINAR: I'm going to try...

She goes, still distressed, leaving Einar alone.

(Coxon, 2015:30)

The fourth ethical dilemma occurred when Gerda asked Einar to go to a party with her as Lili since she knew that her husband was a shy guy who did not like to talk to many people. At the party, Lili met a guy that was Henrik Sandahl. He was so attracted to Lili, and he decided to talk to her and even kiss her. When Gerda tried to look for Lili at the party, she was so shocked since she saw Lili was kissing a guy. She approached them, reached Lili's hand and went home. When they got home, Gerda asked Lili what had just happened at the party. She tried to remind Einar that he dressed as Lili was just a game and asked him to stop acting like a woman. Einar was surprised when he heard what Gerda said. Instead of giving a response by saying a definite answer - such as yes or no - he, with genuine anxiety, answered it by giving an uncertain answer whether he would try to stop. His uncertain answer here showed his ethical dilemma. At that time, he felt that Lili persona already grew in him, and he was not able to stop it. He could not tell the truth to Gerda because he knew it would hurt her, which indicated his superego. Here, his desire to tell Gerda the truth about what happened in him and his unwillingness to make it stop showed his id. In other words, his id drove him to do what he wanted. Yet, his id and superego were suppressed by his ego that he would try his best to do what Gerda asked.

The Lili portraits are gone. Einar regards a canvas. Failing to paint. In the kitchen, Gerda chops vegetables, throws them in a pan. She hovers in the doorway to the studio.

GERDA: Another headache?

EINAR: It's nothing...

She goes back into the kitchen again...

GERDA: Can I get you something?

EINAR: I'm fine. Gerda returns to chopping. GERDA: Maybe you should see a doctor.

Einar grows agitated.

EINAR : Gerda... I'm fine.

Gerda looks round to see Einar now in his coat. He quickly collects a small suitcase, goes out, leaving Gerda to fret.

(Coxon, 2015:31)

The fifth ethical dilemma occurred after he fought with Gerda. They fought because Einar kissed someone else at the party. Gerda saw Einar's face was so pale and anxious, which made her so worried about his condition. She asked him to see a doctor since she knew that there was something wrong about Einar. The man, who did not want to make his wife worried, chose to lie 
about his feelings by stating that he was fine. However, he was unable to have a chat with Gerda because he was still confused about his true self. He did not know whether he had to get rid of Lili's personality or let it grow in him with the risk that it would make Gerda so angry with him. It showed his ethical dilemma. In the end, he decided to go to the Opera House while carrying his suitcase to find the solution to the confusion he experienced. Here, his id appeared when he did not want to tell Gerda about his condition. He did not want to make his wife get worried and did not want to make the situation worse which indicated his superego. It made him unable to express what he truly felt about his wife which indicated his ego. In this case, his id and superego were suppressed by his ego.

Henrik welcomes Lili at the open door...

HENRIK: Come in..

He closes the door against the world. Lili takes in the space. She's delighted by it-

LILI: I don't have long... Gerda's seeing Rasmussen.

Henrik gestures for Lili to sit. She settles on the couch.

HENRIK: I don't like all these lies.

LILI: She's very protective.

HENRIK: Why don't you just tell her about us?

LILI: I couldn't do that...

Lili seems a little panicked...

HENRIK: Sorry - I don't want to upset you.

(Coxon, 2015:33)

Next, the ethical dilemma from the dialogue above happened when Einar was visiting Henrik's house without telling Gerda. Lili told Henrik that she did not have much time to talk to him because she was afraid that Gerda would get home before she did. Hearing what Lili said, made Henrik question several questions to her. He was wondering why Lili did not tell Gerda about their relationship and asking her to tell the truth to Gerda about their relationship. She did not know what kind of response she should give to Henrik when she heard what he said. She did not want to tell it to Gerda because she knew that it would make Gerda angry and hurt her feelings. Also, she was afraid that Henrik would know about her identity if she told him the real reason. However, she knew that she had to tell Gerda about her secret relationship with Henrik and tell Henrik about her identity that she was previously a man in a physical way, which indicated her superego. In the end, Lili could not grant Henrik's request and answer his question. Here, Lili's wish to tell the truth to Gerda and Henrik indicated her ego. Yet, her superego and ego were suppressed by her id that she did not tell the truth to Henrik and Gerda.

HENRIK (cont'd): Come here...

Lili lets herself be drawn closer to him... He strokes her face. Lili smiles, adoring. Henrik kisses her and she responds eagerly. His hand works its way down her body, between her legs. Lili squirms, uncomfortable. He persists... Lili bears it as long as she can, then gently:

LILI: No... Henrik...

HENRIK: Yes...

LILI: No...

Still in the moment of passion...

HENRIK: Einar...

Lili recoils, stunned... astonished...

LILI: What...?

HENRIK (sweetly): Come on... it's alright... But Lili pushes him away, upset, bewildered..

LILI: I'm sorry, I don't understand...

Henrik's frustrated.

HENRIK: Einar... please..

Lili panics, grabs her things to leave, horribly exposed...

LILI: I don't know what you mean... I don't know what you want...

HENRIK: I want you!

LILI: No...

(Coxon, 2015:34)

The ethical dilemma from the dialogue above occurred when Lili came to meet Henrik in his house without telling Gerda. He looked at her face, drowned into her beauty and began to kiss her. He kissed her intently and tried to touch another part of her body. It made Lili feel so uncomfortable and asked him to stop. However, Henrik still asked her to let him touch her. When he persuaded her, instead of calling her name 'Lili' he called her 'Einar'. It made Lili panicked since she thought Henrik did not know about her 
identity and made her realize that she was a man who already had a wife. Her ethical dilemma occurred when she felt disgusted with herself, felt ashamed and wanted to be angry with Henrik for calling her 'Einar', but she could not do it because she knew that Lili loved him and she did not want to make Henrik hate her. In this part, her id was successfully suppressed by her superego. In the end, Lili decided to go home and leave him alone. Here, her ego was manifested in his action by choosing to leave Henrik's house and kept her anger for herself.

GERDA (cont'd): So... are you in love with Sandahl?

Einar's appalled:

EINAR: No - I love you, Gerda, only you. But Lili...

Angry tears well in Gerda's eyes.

GERDA: Why can't you just be honest about this!

But Einar's angry too...

EINAR: I'm trying! Gerda... please... I need you to believe me.

You of all people to understand.

(Coxon, 2015:36)

Next, Einar's ethical dilemma occurred when Gerda walked into the kitchen and saw Einar was crying. Gerda, who was so worried, asked him about his condition. Einar explained that he had been seeing Henrik Sandahl without telling her. Hearing what he said made Gerda shocked and question about his feelings for Henrik. When she asked the reason why he was not honest with her about his feelings towards Henrik, he said that it was very hard for Einar to explain it. It was so hard for him to do so because he did not want to hurt her and was also afraid that Gerda would leave him, but he also knew that Gerda had a right to know the truth of his feelings for Henrik, which showed his ethical dilemma. In this case, his unwillingness to tell Gerda about his feelings for Henrik indicated his id. It emerged because he did not want to hurt Gerda, and he realized that having feelings for someone besides his wife was wrong, which showed his superego. However, he felt that Gerda deserved to know, which made him tell Gerda the truth about his feelings for Henrik. It showed that his id and superego successfully were suppressed by his ego.

Thus, the character of Einar Wegener/Lili Elbe had experienced ethical dilemmas before he made decisions. He had to face by two choices, which made him have to think about what risks would occur when he chose one of the two choices. Also, he represented ego more than the other two parts of psyche. In other words, he was able to control his id and superego.

\section{The Ethical Dilemmas of Gerda Wegener}

Gerda Wegener was Einar's wife who worked as a portrait painter. Gerda's character is very different from Einar's. She is a cheerful, talkative, very confident woman, but she is a bit selfish and stubborn. She was the one who had awakened Einar's true self. She was very supportive of the self-change that happened to her husband. She cared for her spouse and continued to live with Lili after her transition, despite their separation. The only thing she did not approve was when Einar decided to do an ovarian transplant because Gerda thought it was too dangerous. In the screenplay, it showed her ethical dilemmas that are portrayed in certain dialogues below and analyzed by applying the tripartite model of the psyche.

EINAR (cont'd): Lili fell for him. And he kissed her. Just once.

Einar darkens at the memory:

EINAR (cont'd): But my father came in and he caught them... He knocked Hans down - he was so angry...

Einar shakes his head... Gerda absorbs this. She looks up - Einar looks pale, dark circles under his eyes.

GERDA: I don't know what to say.

(Coxon, 2015:37)

The first ethical dilemma on Gerda occurred when Einar told Gerda about his past with Hans. He told Gerda that Lili used to like Hans and they kissed. Gerda was so shocked by hearing Einar's story. She did not expect that her husband had a feeling for a guy when he was a 
teenager. She felt sad and disappointed, and the story caught her completely off guard. She did not respond to it, because she did not want to say anything emotionally to Einar even though she wanted to argue with him for not being completely honest to her. Here, her desire to be mad at him indicated her id. Her superego appeared when she felt that she would hurt Einar's heart and make the situation more complicated if she argued with him. However, as a wife, she had to accept Einar's past with Hans even though it was very hard for her which showed her ego. In this case, her superego told her not to say anything emotionally to Einar to not hurt his feelings.

RASMUSSEN: And there's more - I had a call from the Etienne Dufour Gallery - they would like to represent you in Paris.

GERDA: In Paris...?

RASMUSSEN: You should go and see them.

Gerda's mind races...

GERDA: Oh - I can't travel just now...

RASMUSSEN (firmly): Gerda, this is your moment. You've waited long enough... And these dealers can be fickle.

(Coxon, 2015:41)

The dialogue above showed that Gerda was not sure to do what Rasmussen asked. He asked her to go to Paris for an exhibition after he sold the Lili Portraits, which Gerda had made, to Etienne Dufour Gallery in Paris. At the same time, Einar had just returned from the hospital after undergoing several treatments, and he was still in the recovery phase. It made Gerda be faced with two choices whether she should go to Paris, leave her husband alone or accompany her husband in the recovery phase and not attend the exhibition. Her husband was in a situation where he needed Gerda's support, but the exhibition was really important because that was the highest achievement in her career. However, due to her inability to choose one of the choices, Gerda decided to take her husband to go to Paris with her. She thought it was the best choice because she could still take care of Einar, and could also attend the exhibition. In this case, her ego led her action.

HANS: I don't think so. Could I take you to dinner? To celebrate? Someone ought to.

GERDA: No. Thank you.

Hans absorbs this, regroups.

HANS: Gerda, have I offended you?

GERDA: No.

HANS: Gerda...

He rests his hand on her arm, pressing for some honesty... Gerda's cornered, the heat of the room, the nearness of Hans.

GERDA: I am still Einar's wife.

She brushes past him, into the crowd.

(Coxon, 2015:56)

Next, Gerda's ethical dilemma occurred when Gerda met Hans at the exhibition. He approached her and congratulated her on what had been achieved by her. On that night, Einar chose to stay at home than to attend his wife's event, because he was shy and did not like the crowd. Seeing Gerda who was alone without Einar, Hans invited Gerda to dinner, but she refused it. Hans still tried to invite Gerda by holding Gerda's hand, which made her very surprised. She did not expect that Hans would dare to ask his friend's wife out, and even held her hand. At that time, Gerda was very angry with Hans. She wanted to yell at him for what he did, but she could not do that because that night was her exhibition and was filled with many people that made her not to want to spoil the moment. In this part, her id was successfully suppressed by her superego. Then, she decided to remind Hans nicely that she was still Einar's wife and she left Hans. In this case, her ego triumphed over her action.

Hans heads for his building, is amazed to see Gerda on the front step...

HANS: Gerda... what is it?

She gets to her feet...

HANS (cont'd): You're soaked...

He goes to comfort her, and she embraces him... initiates a desperate snatched kiss before breaking away, upset. Hans pursues her...

HANS (cont'd): Gerda... wait...

GERDA: I can't...

HANS: Wait...

He hurries to catch up. 
(Coxon, 2015:59)

Next, she experienced another ethical dilemma when Gerda and Einar fought after she returned home from the exhibition and after the incident that Hans tried to ask her out to dinner and held her hand. After the fight, she left the apartment and Einar alone. Since she did not know anyone in Paris except Hans, she decided to go to Hans's apartment. It turned out that Hans was not at home, she ended up waiting in front of his room. Not long after, Hans arrived in front of his room and saw her soaking wet, which made Hans try to calm her down. At that time, Gerda did not know what to do. She just needed attention and affection from her husband, but her husband could not give those things to her, and instead got it from another man. The desire to get attention and affection from her husband showed her id. With all the attention Hans gave, it lured her to kiss him. When kissing Hans, she realized that what she did was wrong since she was still Einar's wife. In such a way, her superego triumphed over her action. She immediately ran away leaving Hans and his apartment. In this case, her ego told her to get out of his apartment and leave Hans behind. Here, Gerda's ethical dilemma emerged when she was faced with two options whether fully receiving Hans's attention or leaving Hans and coming back to her husband, even though her husband was not the same person as before.

HANS: Rasmussen called. The Dufour people want you in their group show. I like the idea.

Gerda looks across at him, hasn't heard anything.

GERDA: I'm sorry?

HANS: The Dufour Gallery?

But Gerda shakes her head. Hans sighs, considers, then:

HANS (cont'd): Gerda, why don't you go...? GERDA: He asked me not to.

HANS: He wanted to protect you. You should be there. I'll go with you.

(Coxon, 2015:72)

From the quotation above, Gerda felt the dilemma when Einar left for Dresden to undergo an operation. Hans saw Gerda was very worried about her husband's condition there. She became more quiet than usual. At that time, Gerda was very confused and felt bad for not being there, but she could not go since her husband asked her to stay. She could not even focus on what Hans said. She wanted to go to Dresden, but her husband did not allow her to go because he did not want to hurt Gerda by seeing her husband transformed into a complete woman. She also felt it was very wrong just sitting with Hans and acting as if nothing had happened, which indicated her superego. In this case, her desire to go to Dresden showed her id. In other words, her id drove her to do or follow her will and desire. Yet, it was suppressed by her ego that she did not go because Einar asked her to stay.

LILI (CONT'D): I'm going on Friday. Will you come with me?

Gerda's mind races to absorb the announcement...

GERDA: I won't help you to hurt yourself.

Lili bites down on it:

LILI: Gerda, will you come...?

(Coxon, 2015:82)

Gerda's ethical dilemma from the quotation above had emerged when Einar decided to go to Dresden for the second operation. At that time, she did not agree with his decision because she felt that Einar was not strong enough to undergo the second operation. Seeing Einar's condition, she was afraid that the operation could kill him. However, Einar had already made up his mind to go. He asked Gerda to come to Dresden with him, but she refused it. Then, Einar tried to ask her again, but Gerda did not say anything. At that time, she did not know whether she would come with him or not. Her superego arose when she thought that if she came with him, that meant she supported his decision, whereas she knew it was not the right time to undergo the operation. Yet, she also wanted to accompany him through his process which showed her id. In the end, she decided not to go with him. She had to do that to hope that Einar would understand her and change his mind by not going to Dresden. In this case, her action indicated her ego. 
Hence, Gerda Wegener, in this screenplay, had experienced ethical dilemmas in certain dialogues. Also, her ego played more roles in making decisions when she experienced ethical dilemmas than the other two parts of psyche. In other words, she was able to control her id and superego.

\section{CONCLUSION}

Based on the analysis, it can be concluded that the major characters in The Danish Girl movie screenplay experienced ethical dilemmas when they faced with two choices before they made a decision in their actions. They always experienced an ethical dilemma. The ethical dilemmas happened to them because they needed to think about the impact of their action on other people or themselves. It could prevent them from doing or saying inappropriate things which could hurt someone's feelings or harm themselves. Another conclusion in this study is the ethical dilemmas that happened to the major characters mostly represented ego more than the other two parts of psyche. They could control what they wanted to say or do since they thought about the possible things that could happen in each choice before they made the decision.

\section{REFERENCES}

Bressler, Charles E. (1999). Literary Criticism: An Introduction to Theory and Practice (2nd ed). New Jersey: Prentice Hall.

Burns, S.N \& Grove, S.K. (2003). Understanding nursing study (3rd ed.). Philadelphia: Saunders.

Figar, N., \& Đorđević, B. (2017). Managing an Ethical Dilemma. Economic Themes, 54(3),345-362. https://doi.org/10.1515/ethemes-20160017

Hunt, S. D., and Vasquez-Parraga, A. Z. (1993). Organization consequences, marketing ethics, and sales force supervision. Journal of Marketing Study, 30, 78-90.

IMDb. (2015). The danish girl. Retrieved from https://www.imdb.com/title/tt0810819/

Jones, T. M. (1991). Ethical decision making by individuals in organization: An issue contingent model. Academy of Management Review, 16, 366-395.

Kitchener, K. S. (1984). Intuition, critical evaluation, and ethical principles: The foundation for ethical decisions in counseling psychology. The Counseling Psychologist, 12, 43-55.

Laine, M.D. (2000). Fieldwork, participation and practice: Ethics and dilemmas in qualitative study. London: Sage Publications Ltd. https://doi.org/10.1192/bjp.112.483.211-a

White, T.I. (1998). Resolving an ethical dilemma. Point of View, 36(1), 4-6. Retrieved from http://search.ebscohost.com/login.aspx?direc $\mathrm{t}=$ true $\& \mathrm{db}=\operatorname{cin} 20 \& \mathrm{AN}=1999045248 \&$ site $=\mathrm{eh}$ ost-live 